\title{
The roles of insect cocoons in cold conditions
}

\author{
HuGH V. DANKS \\ Biological Survey of Canada (Terrestrial Arthropods), Canadian Museum of Nature, P.O. Box 3443, Station "D", \\ Ottawa, ON K1P6P4, Canada; e-mail: hdanks@mus-nature.ca
}

Key words. Cocoons, cold, freezing, silk, ice, heat gain

\begin{abstract}
The cocoons characteristic of the prepupal and pupal stages of many insects vary widely in size, durability, structure, shape and colour, as well as in other features such as orientation and attachment to the substrate. In some species they vary seasonally. Most cocoons provide little direct insulation, although they may reduce the rate at which temperature changes, but many provide the mechanical protection required for overwintering beneath insulating substrates such as soil and snow. The cocoons of some terrestrial species prevent inoculative freezing by isolating the integument from ice crystals on the cocoon surface or its surroundings. In some aquatic species, cocoons appear to limit damage by providing mechanical protection during the freezing of surrounding water. Some cocoons help in the acquisition of solar heat: dark structures are especially effective because dark pigments absorb heat, and surrounding layers trap this heat. Insects are immobilized when it is cold and so cannot move in response to environmental threats, and protective cocoons made for winter tend to be more robust than their summer counterparts. Such cocoons protect against abrasion of the waterproof layer of the cuticle. In some species, robust cocoons or complex structures impede natural enemies. Cocoon silk has anti-bacterial and anti-fungal actions. Other cocoons are more or less waterproof. These and other features withstand simultaneous constraints in addition to cold. Therefore, cocoons enhance survival during cold conditions in many species. However, this conclusion is based on fragmentary evidence, and there has been relatively little explicit examination of the roles of cocoons during winter. Therefore, specific work is required to assess resistance to or enhancement of inoculative freezing, resistance to penetration by natural enemies and water, the roles of particular cocoon silks and silk constituents, and the quantitative contributions of cocoons to winter survival in nature.
\end{abstract}

\section{INTRODUCTION}

Many species of insects in many different taxa construct cocoons, some of which incorporate material from the surroundings. Well developed cocoons are especially characteristic of prepupal and pupal resting stages, although partly grown larvae of some species prepare "hibernacula" for winter. In most species, cocoons are assumed to protect their occupants against environmental damage or attack by natural enemies, but these roles have seldom been tested explicitly (Danks, 2002). Specific functions during cold conditions would be expected at least in those species in which cocoon structure varies seasonally.

This paper considers the potential roles that cocoons play when conditions are cold, as listed in Table 1. It evaluates each of these possibilities by reviewing the available scattered information on individual cocoons. Group responses, such as communal tents and nests, are not included (but see Danks, 2002).

\section{FEATURES OF COCOONS}

Cocoons are constructed from silk, fibrous proteins containing repetitive sequences of amino acids, especially alanine, glycine and serine, that are stored as a liquid but configure into solid filaments when spun upon secretion (Craig, 1997; Fedič et al., 2002). Unlike most of the cocoons made from it, silk has been studied extensively. One or more types of silk are produced by many species of arthropods from one or more different glands. The best known insect silks are those of lepidopteran larvae and are produced by the labial glands, the homologue of the salivary glands. Typically, core filaments of the structural element fibroin, produced from the posterior section of the silk gland, are coated and fastened together with a layer of sericin produced in the middle section (Sehnal \& Akai, 1990; Fedič et al., 2002). Fibroin and sericin each comprise a family of related but different proteins. Some other proteins are also present in the silk (see below). Silk from glands dedicated to silk production in insects usually serves for protection (Craig, 1997), in the broad sense that it is used to prepare structures that enclose the individual.

The physical properties of silk vary greatly as a result of the amino acid sequence and dimensional structure of constituent molecules and whether or not they are stressed or "spun" on production, as in Lepidoptera and Hymenoptera (Craig, 1997). Spiders have especially diverse silks and well developed spinning devices, and up to 9 types of silk protein and 9 different silk glands are known in some spiders (Nentwig, 1987; Craig, 1997; Vollrath \& Knight, 2001). Most focus has been placed on the mechanical properties including the great strength of these "biopolymers". Silks vary widely in the degree of tensile strength, permanent or temporary elasticity, stickiness and other properties. Therefore, adaptive modification of the properties of silks and the cocoons made from them seems likely. Non-structural roles also have been attributed to silk constituents. In particular, several proteins that are smaller than the main fibroin and sericin components appear to serve defensive anti-bacterial and 
TABLE 1. Summary of the potential roles of cocoons in cold conditions.

\begin{tabular}{ll}
\hline Feature & Potential roles \\
\hline Cold & $\begin{array}{l}\text { Insulate } \\
\text { Resist drying } \\
\text { Acquire heat }\end{array}$ \\
Ice & $\begin{array}{l}\text { Prevent inoculative freezing } \\
\text { Resist mechanical forces }\end{array}$ \\
Immobility & $\begin{array}{l}\text { Protect against water loss, mechanical damage } \\
\text { and natural enemies while dormant }\end{array}$ \\
Other & $\begin{array}{c}\text { Other roles integrated with roles in cold (see text } \\
\text { and Table 2) }\end{array}$ \\
\hline
\end{tabular}

anti-fungal roles (Akai, 1977; Nirmala et al., 2001a, b; Fedič et al., 2002; Kurioka \& Yamazaki, 2002).

Dependent partly on their constituent silks, insect cocoons vary widely in relative size, durability, structure, shape, colour and other features (Table 2). The potential effects of different cocoon types, which are indicated in the final column of Table 2, have generally been suggested or supposed without adequate documentation or explicit experiments in either warm or cold regions. For example, the colour of cocoon silk can vary, even in one species (Peigler, 1993), suggesting potential functions in camouflage, heat absorption or light transmission. Some variations of silk colour in insects may depend simply on food or other conditions experienced by the larvae, but some of the variations in colour are genetic (e.g. Doira et al., 1997 report silkworm mutations giving yellow, green, reddish brown and other cocoon colours). Although these differences are without known ecological significance, work on spiders shows that certain web reflectances attract prey, and there is evolution in spectral properties (Craig et al., 1994) and colour modification according to habitat (Craig, 1994; Craig et al., 1996). Therefore, adaptive modification in cocoon colour in insects would be possible.

\section{PROTECTION AGAINST COLD AND DRYNESS}

Most cocoons provide little direct insulation (e.g. Sakagami et al., 1985), although they may reduce the rate at which changes in temperature are experienced by the occupants. However, many cocoons provide mechanical protection (and see below) that is required for overwintering in substrates such as soil. In such habitats insulation is provided by the substrate or by overlying snow (cf. Danks, 1991).

The inner layer of the cocoon of the braconid wasp Acampsis alternipes (Nees), within which the emerged adult overwinters prior to activity very early in spring, retains a secretion that surrounds the meconium and contains more than 50\% glycerol and fatty acids (Shaw \& Quicke, 2000). Such a secretion would provide marked cryoprotection.

Exposed habitats during cold winters often are extremely dry (Ring \& Danks, 1994; Danks, 2000), and cocoons can provide protection against desiccation at this time by reducing transpiration of their owners (Canard \& Vanier, 1992; Rosner \& Führer, 1996), although this potential role has more often been demonstrated for temperate species at other times of year (e.g. Nowbahari \& Thibout, 1990; Tagawa, 1996; Zamora-Munoz \& Svensson, 1996).

TABLE 2. Range of features of insect cocoons and some potential effects of modified features (from information summarized in Danks 1987, Table 6, and many other sources; see text for some examples).

\begin{tabular}{llll}
\hline Feature & Simple condition & Modification & Potential effect of modification \\
\hline Relative size & $\begin{array}{c}\text { Loosely around } \\
\text { occupant }\end{array}$ & Tightly applied to occupant & Resistance to some kinds of damage \\
Robustness & Flimsy & Tough and durable & $\begin{array}{l}\text { Resistance to damage } \\
\text { Reduced permeability to water vapour and toxic } \\
\text { substances }\end{array}$ \\
Structure & Simple tube & $\begin{array}{l}\text { Includes complex exit } \\
\text { structures, etc. }\end{array}$ & Facilitates adult emergence \\
Structure of wall & One thin layer & Complex, thick, double & Protection against inoculative freezing, predators, \\
& & & etc.
\end{tabular}




\section{PROTECTION AGAINST ICE}

Cocoons serve in two ways to protect against surrounding ice during winter. In some terrestrial species, the cocoon wall isolates the prepupal or pupal integument from ice crystals on the surface or surroundings of the cocoon, and thus maintains supercooling by preventing inoculative freezing (e.g. Sakagami et al., 1985).

In some aquatic species, cocoons appear to limit damage by providing mechanical protection during the freezing of surrounding water and its expansion to ice. Chironomid midges make special winter cocoons that are believed to serve this role. Such winter cocoons are much more robust than the summer feeding shelters of the same species, with thicker walls but incorporating much less substrate material. Moreover, they are tightly applied to the bodies of the larvae, which are folded within them in characteristic ways according to species (review by Danks, 1971; Danks \& Jones, 1978; Kornijów, 1992). Comparably robust aestivation cocoons in species from temporary water bodies (e.g. Grodhaus, 1980) presumably serve to protect against mechanical damage too.

Several properties of silks are potentially relevant in freezing conditions. For example, spider silk enhances ice nucleation: the mean supercooling point of $10 \mu 1$ droplets of distilled water is $-14.1^{\circ} \mathrm{C}$ alone but $-7^{\circ} \mathrm{C}$ with silk of the agelenid spider Agelena opulenta L. Koch (Murase et al., 2001). In the presence of $100 \mathrm{ppm}$ of ice-nucleating protein, a particularly effective ice nucleator, freezing of similar droplets occurs at $-3.5^{\circ} \mathrm{C}$. Silkworm sericin has potential as a cryoprotective agent for cells or enzymes (Tsujimoto et al., 2001). However, it is not clear how such properties of purified cocoon elements might be relevant in nature.

\section{HEAT GAIN}

Some cocoons help in the acquisition of solar heat. Dark structures are especially effective, because dark pigments absorb heat, and surrounding hairs, loose fibres or transparent layers trap this heat by restricting disturbance of the warm boundary layer by wind or convection. Solar heating of this sort is well known in individual insects and plant parts especially from the arctic (Kevan, 1973, 1975, 1989, 1990; Kukal, 1991). Kevan (1973) classified heated arctic flowers as microgreenhouses, hairy heat traps, hanging bells, solar furnaces and flared bells. Parallel adaptations for solar heating have been demonstrated in cocoons of the lymantriid moth Gynaephora groenlandica (Wocke), in which (unlike related species) the cocoon is double, with a dark inner layer and a translucent outer layer [Kevan et al., 1982 (as G. rossi); Lyon \& Cartar, 1996].

The heat gained by such structures, for example as much as $14^{\circ} \mathrm{C}$ above ambient in summer (Kevan et al., 1982), is influenced by their orientation. The cocoons of Gynaephora groenlandica, reflecting the behaviour of the caterpillars that build them, appear to be aligned to maximize solar heat gain by exposure to the sun and to reduce convective heat loss by minimizing exposure to prevailing winds (Kevan et al., 1982; Lyon \& Cartar, 1996).

\section{OTHER ROLES DURING INACTIVITY}

When it is cold, insects (like other poikilotherms) are immobilized, whether they are merely quiescent or enter diapause. Cocoons protect such individuals, which cannot move in response to environmental threats such as dry conditions and natural enemies. For example, cocoons made for diapause or for winter tend to be more sturdy, and may have more layers, than their summer counterparts. Many examples are cited by Danks (1987, Table 6; see also Mello \& Garafalo, 1986; Donovan, 1991). Typical cocoons are anchored in winter, like some of the summer structures, to prevent displacement by wind or water currents (e.g. Gardiner, 1982; Hauer \& Stanford, 1982).

Robust and immobile cocoons would protect against mechanical damage or abrasion of the waxy waterproof layer of the cuticle (cf. Goto et al., 1997). Some cocoons protect against natural enemies. Robustness resists penetration by parasitoids and predators. Very tough cocoons can be penetrated by only a few such species (references cited by Gross, 1993). Even when the cocoon wall can be penetrated more easily, the ovipositors of some parasitoids cannot reach their target inside, because the hosts build relatively large cocoons (cf. Gross, 1993). Suspension or complex structures, such as flocculent threads on the surface, also may impede parasitoids and predators (Gross, 1993; cf. Hieber, 1992 for spider egg "cocoons"). Cocoon silk has anti-bacterial and anti-fungal actions (see above). Other cocoons are more or less waterproof, defending against immersion (e.g. Sagné \& Canard, 1984 for the lacewing Chrysopa perla (L.) in winter; some bees use waxes or resins for waterproofing, e.g. Roubik \& Michener, 1980). Moreover, many general functions of cocoons persist in winter, when they may be especially important even though metabolism is suppressed because dormancy lasts for such a long time.

\section{INTEGRATION OF ROLES}

Cocoons have many roles, some of which have no particular linkages with cold (for example during summer activity), including protection against physical conditions, toxic substances (e.g. Bartell et al., 1976; Halpern et al., 2002), natural enemies, and in relation to resources (cf. Danks, 2002). Robust shelters protect against a variety of physical conditions and against natural enemies, although such structures are costly in resources for building (cf. Stevens et al., 1999 for caddis cases). Silk comprises a significant proportion, up to $50 \%$ or more of the weight, of many prepupal larvae just before they spin cocoons. For example, the silk cocoon weighs as much as the pupa in the commercial silkworm Bombyx mori L. as well as in some saturniid moths (e.g. Dash et al., 1992). More than $10 \%$ of prepupal weight is devoted to cocoon production even in many Hymenoptera (e.g. Bosch \& Vicens, 2002).

Cocoons have also been implicated in mediating information for control of the life cycle, including the attenuation or transmittal of photoperiodic cues to induce diapause. Williams et al. (1965) showed that the cocoon of the silk moth Antheraea pernyi (Guérin-Méneville) 
acts as a light-integrating sphere, so that light intensity for the pupa within the cocoon is much higher than would be expected from the amount transmitted directly through the cocoon walls. The diapause cocoons of the braconid Microplitis demolitor Wilkinson appear to mediate the effects of an increase in humidity that ends diapause (Seymour \& Jones, 2000). Diapause ends earlier in individuals not enclosed in a cocoon, suggesting that some substance in the cocoon is degraded by humidity, whereupon the humidity cues that end diapause can be perceived by the prepupa within (Seymour \& Jones, 2000, p. 484).

General cocoon functions often are integrated with those linked to cold, because many cocoon features (cf. Table 2) can serve several simultaneous functions. For example, the robust cocoons of the moth Leguminivora glycinivorella (Matsumura) protect against flooding as well as ice inoculation (Sakagami et al., 1985). Stout caddis cases can provide camouflage or mechanical protection against bird predation (cf. Otto, 1983), resist drying (Zamora-Munoz \& Svensson, 1996), and prevent displacement.

Cocoons or cocoon silks have other properties that probably have no adaptive value but reflect features of silk as a material. For example, cocoons (and the cuticle) of the wasp Vespa orientalis L. have photoelectric properties, transducing light into electrical energy (Ishay et al., 1992).

\section{CONCLUSIONS}

Although evidence is fragmentary, cocoons in many species clearly play important roles in enhancing survival during cold conditions. They allow insulated habitats to be occupied in winter, offset the effects of ice, and withstand biotic and abiotic challenges during inactivity. However, there has been relatively little specific examination of these roles. In future, therefore, features of cocoons have to be characterized explicitly. For example, studies of the properties of component silks should not be confined only to mechanical strength and the potential for commercial applications, but should cover a wider range of features likely to be of adaptive value to cocoon occupants. Examining cocoon structures and silk properties, including comparisons among related species from different climates and habitats, would help to quantify such features as resistance to inoculative freezing and penetration by natural enemies and water. In particular, carefully designed experimental work is required to measure the contributions of the various features of cocoons to winter survival in nature.

\section{REFERENCES}

AKAI H. 1977: Anti-bacterial function of natural silk materials. Int. J. Wild Silkmoth Silk 3: 79-81.

Bartell D.P., SANBorn J.R. \& Wood K.A. 1976: Insecticide penetration of cocoons containing diapausing and nondiapausing Bathyplectes curculionis, an endoparasite of the alfalfa weevil. Environ. Entomol. 5: 659-661.

Bosch J. \& Vicens N. 2002: Body size as an estimator of production costs in a solitary bee. Ecol. Entomol. 27: 129-137.
CAnARd M. \& Vannier G. 1992: Adaptations of preimaginal stages of Nineta pallida (Schneider) to frost and heat (Insecta: Neuroptera: Chrysopidae). In Canard M., Aspöck H. \& Mansell M.W. (eds): Current Research in Neuropterology. Proc. $4^{\text {th }}$ Int. Symp. Neuropt. Sacco Press, Toulouse, pp. 75-85.

CRAIG C.L. 1994: Limits to learning: effects of predator pattern and colour on perception and avoidance-learning by prey. Anim. Behav. 47: 1087-1099.

Craig C.L. 1997: Evolution of arthropod silks. Annu. Rev. Entomol. 42: 231-267.

Craig C.L., Bernard G.D. \& Coddington J.A. 1994: Evolutionary shifts in the spectral properties of spider silks. Evolution 48: 287-296.

Craig C.L., Weber R.S. \& Bernard G.D. 1996: Evolution of predator-prey systems: spider foraging plasticity in response to the visual ecology of prey. Am. Nat. 147: 205-229.

DANKS H.V. 1971: Overwintering of some north temperate and arctic Chironomidae. II. Chironomid biology. Can. Entomol. 103: $1875-1910$.

DANKs H.V. 1987: Insect Dormancy: An Ecological Perspective. Biological Survey of Canada (Terrestrial Arthropods), Ottawa, 439 pp.

DANKS H.V. 1991: Winter habitats and ecological adaptations for winter survival. In Lee R.E. Jr. \& Denlinger D.L. (eds): Insects at Low Temperature. Chapman \& Hall, New York, London, pp. 231-259.

Danks H.V. 2000: Dehydration in dormant insects. J. Insect Physiol. 46: 837-852.

DANKS H.V. 2002: Modification of adverse conditions by insects. Oikos 99: 10-24.

DanKs H.V. \& Jones J.W. 1978: Further observations on winter cocoons in Chironomidae (Diptera). Can. Entomol. 110: 667-669.

Dash A.K., Nayak B.K. \& Dash M.C. 1992: The effect of different foodplants on cocoon crop performance in the Indian tasar silkworm Antheraea mylitta Drury (Lepidoptera: Saturniidae). J. Res. Lepid. 31: 127-131.

Doira H., Fujil H., Kawaguchi Y., Banno Y. \& Shimada T. 1997: Mutations of Bombyx mori. In Silkworm genome database,http://www.ab.a.u-tokyo.ac.jp/bioresource/shimada/ mutants.html

Donovan B.J. 1991: Life cycle of Sphecophaga vesparum Curtis (Hymenoptera: Ichneumonidae), a parasitoid of some vespid wasps. N. Z. J. Zool. 18: 181-192.

Fedič R., Žurovec M. \& Sehnal F. 2002: The silk of Lepidoptera. J. Insect Biotechnol. Sericol. 71: 1-15.

GARDINER B.O.C. 1982: A silkmoth rearer's handbook, 3rd ed. Amateur Entomologist 12. 255 pp.

Goto S.G., Tagawa M. \& Kimura M.T. 1997: The effect of age, sex and diapause on desiccation tolerance in Drosophila triauraria (Diptera, Drosophilidae). Jpn. J. Entomol. 65: 362-368.

Grodhaus G. 1980: Aestivating chironomid larvae associated with vernal pools. In Murray D.A. (ed.): Chironomidae. Ecology, Systematics, Cytology and Physiology. Proc. $7^{\text {th }}$ Int. Symp. on Chironomidae, Dublin 1979. Pergamon Press, Oxford, pp. 315-322.

Gross P. 1993: Insect behavioral and morphological defenses against parasitoids. Annu. Rev. Entomol. 38: 251-273.

Halpern M., Gasith A. \& Broza M. 2002: Does the tube of a benthic chironomid larva play a role in protecting its dweller against chemical toxicants? Hydrobiologia 470(1-3): 49-55.

Hieber C.S. 1992: Spider cocoons and their suspension systems as barriers to generalist and specialist predators. Oecologia 91: $530-535$. 
Hauer F.R. \& Stanford J.A. 1982: Bionomics of Dicosmoecus gilvipes (Trichoptera: Limnephilidae) in a large western montane river. Am. Midl. Nat. 108: 81-87.

Ishay J.S., Benshalom-Shimony T., Ben-Shalom A. \& KristianPOLLER N. 1992: Photovoltaic effects in the oriental hornet Vespa orientalis. J. Insect Physiol. 38: 37-48.

Kevan P.G. 1973: Flowers, insects and pollination ecology in the Canadian high arctic. Polar Rec. 16: 667-674.

Kevan P.G. 1975: Sun-tracking solar furnaces in high arctic flowers: Significance for pollination and insects. Science 189: 723-726.

Kevan P.G. 1989: Thermoregulation in arctic insects and flowers: adaptation and co-adaptation in behaviour, anatomy, and physiology. In Mercer J.B. (ed.): Thermal Physiology. Elsevier Science Publishers B.V. (Biomedical Division), Amsterdam, pp. 747-753.

Kevan P.G. 1990: Sexual differences in temperatures of blossoms on a dioecious plant, Salix arctica: significance for life in the arctic. Arct. Alp. Res. 22: 283-289.

Kevan P.G., Jensen T.S. \& Shorthouse J.D. 1982: Body temperatures and behavioral thermoregulation of high arctic woolly-bear caterpillars and pupae (Gynaephora rossii, Lymantriidae: Lepidoptera) and the importance of sunshine. Arct. Alp. Res. 14: 125-136.

KorNiJów R. 1992: Seasonal migration by larvae of an epiphytic chironomid. Freshwater Biol. 27: 85-89.

KuKAL O. 1991: Behavioral and physiological adaptations to cold in a freeze-tolerant arctic insect. In Lee R.E. Jr. \& Denlinger D.L. (eds): Insects at Low Temperature. Chapman \& Hall, New York, pp. 276-300.

Kunioka A. \& YamazaKi M. 2002: Purification and identification of flavonoids from the yellow green cocoon shell (Sasamayu) of the silkworm, Bombyx mori. Biosci. Biotechnol. Biochem. 66: 1396-1399.

LyON B.E. \& CARTAR R.V. 1996: Functional significance of the cocoon in two arctic Gynaephora moth species. Proc. R. Soc. Lond. (Ser. B, Biol. Sci.) 263: 1159-1163.

Mello M.L.S. \& Garafalo C.A. 1986: Structural dimorphism in the cocoons of a solitary bee, Lithurgus corumbae (Hymenoptera, Megachilidae) and its adaptive significance. Zool. Anz. 217: 195-206.

Murase N., Ruike M., Matsunaga N., Hayakawa M., Kaneko Y. \& ONO Y. 2001: Spider silk has an ice nucleation activity. Naturwissenschaften 88: 117-118.

Nentwig W. 1987: Ecophysiology of Spiders. Springer-Verlag, New York, 448 pp.

Nirmala X., Kodrík D., Žurovec M. \& Sehnal F. 2001a: Insect silk contains both a Kunitz-type and a unique Kazal-type proteinase inhibitor. Eur. J. Biochem. 268: 2064-2073.

Nirmala X., Mita K., Vanisree V., Žurovec M. \& Sehnal F. 2001b: Identification of four small molecular mass proteins in the silk of Bombyx mori. Insect Mol. Biol. 10: 437-445.

Nowbahari B. \& Thibout E. 1990: The cocoon and humidity in the development of Acrolepiopsis assectella (Lepidoptera) pupae: consequences in adults. Physiol. Entomol. 15: 363-368.
Отто C. 1983: Behavioural and physiological adaptations to a variable habitat in two species of case-making caddis larvae using different food. Oikos 41: 188-194.

Peigler R.S. 1993: Wild silks of the world. Am. Entomol. 39: 151-161.

Ring R.A. \& DANKS H.V. 1994: Desiccation and cryoprotection: overlapping adaptations. CryoLetters 15: 181-190.

RosNer S. \& FÜHRER E. 1996: Zur Überwinterungstrategie der kleinen Fichtenblattwespe, Pristiphora abietina Christ. (Hym., Tenthredinidae). J. Appl. Entomol. 120: 225-230.

RoubiK D.W. \& Michener C.D. 1980: The seasonal cycle and nests of Epicharis zonata, a bee whose cells are below the wet-season water table (Hymenoptera, Anthophoridae). Biotropica 12: 56-60.

SAGNÉ J.C. \& CANARD M. 1984 : Les limites de la résistance au froid et à l'immersion des prénymphes en diapause de Chrysopa perla (L.) (Neuroptera Chrysopidae). Neuroptera Int. 3: 73-78.

Sakagami S.F., Tanno K., Tsutsui H. \& Honma K. 1985: The role of cocoons in overwintering of the soybean pod borer Leguminivora glycinivorella (Lepidoptera: Tortricidae). J. Kans. Entomol. Soc. 58: 240-247.

Sehnal F. \& AKai H. 1990: Insect silk glands: their types, development and function, and effects of environmental factors and morphogenetic hormones on them. Int. J. Insect Morphol. Embryol. 19: 79-132.

Seymour J.E. \& Jones R.E. 2000: Humidity-terminated diapause in the tropical braconid parasitoid Microplitis demolitor. Ecol. Entomol. 25: 481-485.

Shaw M.R. \& Quicke D.L.J. 2000: The biology and early stages of Acampsis alternipes (Nees), with comments on the relationships of the Sigalphinae (Hymenoptera: Braconidae). $J$. Nat. Hist. 34: 611-628.

Stevens D.J., Hansell M.H., Freel J.A. \& Monaghan P. 1999: Developmental trade-offs in caddis flies: Increased investment in larval defence alters adult resource allocation. Proc . R. Soc. Lond. (Ser. B, Biol. Sci.) 266: 1049-1054.

TAGAWA J. 1996: Function of the cocoon of the parasitoid wasp, Cotesia glomerata L. (Hymenoptera: Braconidae): protection against desiccation. Appl. Entomol. Zool. 31: 99-103.

Tsujimoto K., Takagi H., Takahashi M., Yamada H. \& NAKAMORI S. 2001: Cryoprotective effect of the serine-rich repetitive sequence in silk protein sericin. J. Biochem. 129: 979-986.

Vollrath F. \& KNIGHT D.P. 2001: Liquid crystalline spinning of spider silk. Nature 410: 541-548.

Williams C.M., Adkisson P.L. \& Walcott P. 1965: Physiology of insect diapause. XV. The transmission of photoperiod signals to the brain of the oak silkworm, Antheraea pernyi. Biol. Bull. Mar. Biol. Lab. Woods Hole 128: 497-507.

Zamora-Munoz C. \& Svensson B.W. 1996: Survival of caddis larvae in relation to their case material in a group of temporary and permanent pool. Freshwater Biol. 36: 23-31.

Received August 22, 2003; revised March 30, 2004; accepted April 5, 2004 